\title{
Essays
}

\section{The Federal Judicial Law Clerk Hiring Problem and the Modest March 1 Solution}

\author{
Edward R. Becker, ${ }^{\dagger}$ Stephen G. Breyer, ${ }^{\dagger \dagger}$ and Guido Calabresi""
}

\section{INTRODUCTION}

In September 1993 the Judicial Conference of the United States unanimously adopted the following resolution:

The Judicial Conference recognizes as the Benchmark Starting Date for clerkship interviews March $l$ of the year preceding the year in which the clerkship begins.'

$\div$ Circuit Judge, U.S. Court of Appeals for the Third Circuit. B.A., University of Pennsylsania, 1954. LL.B., Yale Law School, 1957. Judge Becker is the primary author of this Essiny. which is bascd upon material gathered by all three authors.

$\div$ Associate Justice, Supreme Court of the United States. A.B. Stanford University. 1959, B A. Oxford University, 1961; LL.B.. Harvard Law School. 1964. At the ume of the events nambled in this Essay, Justice Breyer was serving as Circuit Judge and then as Chief Judge of the U.S. Court of Appeals for the First Circuit.

$+\div$ Circuit Judge, U.S. Court of Appeals for the Second Circuit. B.S.. Yale Unusersily, 1953. B A . Oxford University, 1955; LL.B., Yale Law School. 1958; M.A.. Oxford University, 1959 At the tume of the events narrated in this Essay, Judge Calabresi was serving as the Dean of the Yale Lau Sctool

1. Memorandum from Judge Becker and Chief Judge Breyer to Members of the Judicial Conference 1 (Sept. 8, 1993) (proposing specific language of resolution voted on by Conference) (on file with Judge Becker); see L. RALPH MECHAM (DIRECTOR), ADMIN. OFf, OF THE U.S CTS. REPORT OF THE. PROCEedings of THE JUdiCIAL CONFERENCE OF the UNITEd STATES 49 (Sept. 20. 1993) ("In an cffort to improve the law clerk hiring process, the Judicial Conference voted to recommend to all judicial officers that March 1 of the year before a clerkship begins be the benchmark startung date for law elerk interviews."). 
As submitted to the Judicial Conference, the resolution contained the following explanatory note:

The Benchmark Starting Date is not meant to be binding. The Conference expects that judges will make a good faith effort not to interview candidates before that date, but special circumstances might sometimes call for an earlier interview. This Benchmark Starting Date will be made known to the law schools, with the suggestion that faculties be urged not to transmit letters of recommendation until approximately February 1, which is about the time when third semester grades are available. The suggestion will also be made that law schools advise students that they are not obliged to accept the first offer tendered (there being widespread confusion on this point). ${ }^{2}$

This modest "March 1 Solution" followed years of failed attempts to deal with a process that had seen federal judges hiring law clerks as early as October of their second year of law school. Hiring clerks early on in their law school careers overemphasized first-year grades, caused unnecessary disruption of classes, considerably increased the cost of travel for interviews, vastly raised the anxiety level for the students, and impaired the reputation of the federal judiciary.

The competition among judges to hire prime law clerks tended to push hiring dates earlier and earlier. By 1992, law students scrambled as early as September of their third semester to apply to judges rumored to be hiring. In the fall of 1993, in an attempt to arrest the advancing trend, the Judicial Conference adopted the March 1 Solution. After only one year in operation, it has been strongly endorsed by federal judges, law students, professors, and administrators. Although the Solution may not have been ideal in theory, in practice it was a success.

In order to understand why both judges and law schools should continue to support the March 1 Solution, we sketch the history of prior attempts to solve the law clerk hiring problem, all of which failed to achieve sufficient judicial support to provide lasting reform. We then examine why other approaches to the problem are inadequate and offer our recommendations for improving on the March 1 Solution.

\section{A FEW PAGES OF HISTORY ${ }^{3}$}

Before the mid-1970's, the prevailing practice of federal judges was to select law clerks during the fall of their third year of law school. Gradually,

2. Memorandum from Judge Becker and Chief Judge Breyer to Members of the Judicial Conference I (Sept. 8, 1993) (on file with Judge Becker).

3. "Upon this point a page of history is worth a volume of logic." New York Trust Co. v. Eisner, 256 U.S. 345, 349 (1921) (Holmes, J.). 
the judges' hiring date crept earlier and earlier until most selections were made in the spring of the students' second year. Since the late 1970's, federal judges have made six separate attempts to reform this process."

In 1978, law school deans succeeded in persuading the Association of American Law Schools to issue recommended guidelines for hiring, but most federal judges did not abide by them. In March 1983, the Judicial Conference requested that judges not consider applications before September 15 of the students' third year of law school; by the 1984 season, however, early hiring was rampant. Following a survey of judges' reactions to the September 15 benchmark, the Judicial Conference abandoned the experiment.

In 1986, Stephen G. Breyer, then a circuit judge on the U.S. Court of Appeals for the First Circuit, attempted to build a consensus for the 1986 season by urging federal appellate judges not to consider student applications before April 1.5 A large number of judges responded favorably, both in writing and in actual practice. In 1987 and especially in 1988, however, the April 1 date was largely ignored; many of the judges interviewed and hired in March, and a few in February, of the students' second year.

During the 1989 clerkship season, then Chief Judge Breyer and Judge Edward R. Becker of the U.S. Court of Appeals for the Third Circuit attempted to achieve a consensus among the U.S. circuit judges on a March 1 interview date. ${ }^{6}$ They polled all the circuit judges regarding their willingness to adhere to a March 1 interview date if eighty-five percent of all circuit judges agreed. When only some seventy-five percent of the circuit judges responded positively, Judge Becker notified the judges on January 23, 1989, that "you and your colleagues should feel no constraints about interviewing and selecting law clerks at any time during the forthcoming "season."'?

Soon after Judge Becker's letter, a highly critical and ultimately quite influential article appeared in The New York Times. The author stated:

The once-decorous process by which Federal judges select their law clerks has degenerated into a free-for-all in which some of the nation's most eminent judges scramble for the top law school students.

In their eagerness to capture the best clerks, the judges have steadily pushed up the hiring process; instead of looking for students

4. See Trenton N. Norris, The Judicial Clerkship Selection Process: An Applicant's Perspectuve on Bad Apples, Sour Grapes and Fruitful Reform, 81 CAL. L. REV. 765. 766. 785-88 (1993).

5. See, e.g. Letter from Judge Breyer to Judge Becker I (Jan. 24, 1986) (on file with Judge Becker).

6. Judges Becker and Breyer sought consensus first among U.S. circuit judges in 1989 and later years because of the vastly smaller size of the federal appellate (in contrast to the (nal) judiciary. making it far easier to communicate with and obtain responses from the judges. All such inituauves were taken in the hope that the district judges would follow suit.

7. Letter from Judge Becker to Courts of Appeals Colleagues I (Jan. 23. 1989) (on file with Judge Becker). 
in their third year of law school as custom once required, judges surreptitiously began recruiting second-year students in the fall and offered some jobs as early as February, disrupting studies and making decisions on the basis of fewer grades and flimsier evidence.

"It was positively surreal, the most ludicrous thing I've ever been through," said one Stanford student who recently endured the process. "Here are these brilliant, respected people-they're Federal judges, for God's sake-and they're behaving like 6-year-olds."8

Making reference to the words that start the annual Indianapolis Speedway race, the article's author concluded that, instead of notifying the judges of the absence of constraints, Judge Becker might as well have told them, "Ladies and Gentlemen, start your engines."9

Stung by the article and by other criticism, Judges Becker and Breyer, joined by Chief Judges James Oakes (Second Circuit) and Patricia Wald (D.C. Circuit), initiated a campaign that yielded an agreement for the 1990 season among more than two-thirds of the U.S. circuit judges. Under the 1990 plan, while clerkship interviews could take place at any time, judges would not make offers until May 1 at 12:00 noon Eastern Daylight Time. ${ }^{10}$ The implementation of this more ambitious proposal was also a failure.

There were a few reports of students getting phone calls from judges in the weeks before May 1 asking the students questions of the sort, "If I were to

8. David Margolick, At the Bar: Annual Race for Clerks Becomes a Mad Dash, with Judicial Decorum Left in the Dust, N.Y. TIMES, Mar. 17, 1989, at B4. Chief Judge Alfred T. Goodwin of the Ninth Circuit offered a more colorful description of the process:

There has been a lot of electronic traffic on the annual competition to join the Supreme Court's farm club system. The competition has all of the dignity of the Oklahoma land rush and the efficiency of the calf scramble.

Some of our urban members may never have seen a calf scramble. It is the low point of many western rodeos. A small number of calves are turned loose in the arena, along with a larger number of adolescent cow persons. The latter attempt to seize, subdue and carry out the former. The SPCA writes letters to the editor during the following week.

Memorandum from Alfred T. Goodwin, Circuit Judge, U.S. Court of Appeals for the Ninth Circuit, to [Judicial] Associates 1 (Jan. 4, 1989) (on file with Judge Becker).

9. Margolick, supra note 8, at B4.

10. Letter from Judge Becker to Judge Breyer; Wilfred Feinberg, Chief Judge, U.S. Court of Appenls for the Second Circuit; and Patricia M. Wald, Chief Judge, U.S. Court of Appeals for the District of Columbia Circuit I (Jan. 18, 1989) (on file with Judge Becker); see Letter from James L. Oakes, Chicf Judge, U.S. Court of Appeals for the Second Circuit, to Betsy Levin, Executive Director, Association of American Law Schools 1 (Dec. 11, 1989) (stating that nine of the thirteen circuits "have agreed in principle that no offers will be made to law clerk applicants until 12:00 noon, Eastern Daylight Time, on May 1, 1990, for 1991-92 clerkships and that applicants will have twenty-four-hour lead time for acceptance of such offers") (on file with Judge Becker); Mernorandum from Betsy Levin, Executive Director, Association of American Law Schools, to Deans of Member Schools and Members of the House of Representatives 2 (Jan. 23, 1990) (urging Deans to reinforce efforts of Judicial Circuit Councils) (on file with Judge Becker); Letter from Chief Judge Breyer to Judge Becker, James Oakes, Chief Judge, U.S. Court of Appeals for the Second Circuit; Stephen Reinhardt, Circuit Judge, U.S. Court of Appeals for the Ninth Circuit; and Patricia Wald, Chief Judge, U.S. Court of Appeals for the District of Columbia Circuit 1-2 (Apr. 19, 1990) (suggesting that at noon Eastern Daylight Time, offerees should be given "at least an hour" to consider the offer, and that after the "noon" round it will be "a free for all") (on file with Judge Becker). 
give you an offer, would you accept?" Some judges called applicants promptly at noon only to find that they had accepted another offer a few minutes earlier from a judge whose "watch was fast." Moreover, because the judges had not reached an agreement on how long they were to keep the offers open, a frenzy of offers and acceptances ensued within minutes of the noon hour. As a result, many clerkship applicants did not get their preferred clerkship, and judges who allowed students time to consider an offer and comparison shop discovered that, if the student advised the judge an hour or two later that he or she had accepted another clerkship, the judge's next five or more choices had already committed themselves to someone else. In short, as a follow-up survey among judges showed, nobody ended up happy."

After the 1990 clerkship season, Judge Becker and Chief Judges Breyer, Oakes, and Wald abandoned their reform efforts. Predictably, 1991 was as frenetic as 1989 had been. The next year was even worse. In the 1992 clerkship season, virtually all judges on the D.C. Circuit had finished their hiring by February. Many judges elsewhere did likewise. Some judges made offers in December 1991 to students who were not even halfway through law school.

The downward spiral accelerated the next year when Professor Kent Syverud, clerkship advisor at the University of Michigan Law School, wrote to all federal judges that the Michigan students, so as not to be beaten to the door by the competition, would be applying for clerkships in September of their second year of law school. ${ }^{12}$ The 1993 law clerk hiring scason thus began in earnest in the early fall of 1992, the earliest date ever. A joke began to circulate about competitive judges casing kindergartens for bright young prospects. When a statement to this effect attributed to Judge Becker appeared in the legal press, ${ }^{13}$ one of his former law clerks collaborated with a friend on a mock application:

I know it's early, but my mommy was reading the Legal Times and told me that you know of judges who are accepting resumes from people who had good grades in kindergarten. Although my kindergarten, like Yale, didn't really have grades, I am now a first

11. See Memorandum from James L. Oakes. Chief Judge. U.S. Coun of Appeals for the Second Circuit, to all Second Circuit Judges 1 (Dec. 26. 1990) (notıng that almost half of the judges who participated in 1990's May 1 date considered it unsatisfactory) (on file with Judge Becher)

12. Letter from Kent D. Syverud. Professor. University of Michigan Law School, to Judge Becker I (Aug. 11, 1992) (noting that it "has been our repeated and pannful expenence in the past year that many judges who express a resolve not to be rushed nevertheless end up interviewing and hinng before our students get their applications out") (on file with Judge Becker). Professor Syverud explaıns that his letter of August 1992 was motivated by the embarrassment he suffered in both 1990 and 1991 when students relied on his advice that "distinguished federal judges" would abide by the vanous dates they had set for themselves and then the judges "interviewed much earlier than those dates." Letter from Keni D Syverud. Professor, University of Michigan Law School, to Judge Becker 1-2 (Sept. 20. 1924)

13. Steve Alber, Judges Try To Impose Rules on Scramble for Top Low Clerks. 9th Circut Balks. LEGAL TIMES, Nov. 15, 1993, at 1. 
grader and did super well last year. . . I can count all the way up to 37 without making any mistakes at all, and then I can go usually all the way up to 71 with just a couple of boo-boos. I promise to write opinions that don't have more pages than I can count.

\section{EDUCATION}

\section{Kindergarten}

Grades: Out of 6 projects, 4 Gold Stars, 1 Silver Star, and a Smiley Face.

Class Rank: Second Tallest

Received special school arts-and-crafts award for best papiermâché likeness of Barney the Purple Dinosaur.

Nominated for Inclusion in Who's Who Among American Kindergarten Students.

\section{PUBLICATIONS}

Dick, Jane, and Gender: Deconstructing The "Text" of Childhood, 24 FISHMAN KINDERGARTEN Q. 288 (forthcoming 1994). ${ }^{14}$

The scramble caused by Michigan's announcement of a September start date convinced Chief Judge Breyer and Judge Becker that the time had come to make yet another effort to achieve a semblance of order and decorum. They began by sending a questionnaire to all U.S. circuit judges inquiring whether they would agree to a "benchmark" starting date for law clerk interviews-even if some judges did not honor it. ${ }^{15}$

\section{SETTING THE MARCH 1 BENCHMARK}

After responses to a questionnaire showed overwhelming support among the judges for a "benchmark date,"

14. Application for employment as a judicial clerk from "Adrian Mackensworth" to Judge Becker 1 (Nov. 26, 1993) (ghostwritten by Paul Fishman and Eric Muller).

15. Memorandum from Chief Judge Breyer and Judge Becker to all United States Circuit Judges 1 (Jan. 11, 1993) (on file with Judge Becker).

16. See, e.g., Letter from Francis D. Murnaghan, Jr., Circuit Judge, U.S. Court of Appeals for the Fourth Circuit, to Judge Becker I (Jan. 18, 1993) ("I heartily endorse a recommended date for commencing law clerk interviews. . . . I would prefer an even later date . . . but I recognize that getting agreement on any date [later] than March 1 is extremely unlikely.") (on file with Judge Becker). The tabulated results of the survey follow:

Total Responses Received: 145

Question \#I (Do you endorse a non-binding recommended date for commencement of interviews?)

$\begin{array}{lr}\text { Yes } & 121 \\ \text { No } & 21 \\ \text { Blank } & 3\end{array}$


presented the matter at the February 1993 National Workshop for U.S. Circuit Judges. The consensus among the judges attending the presentation was that any action, to be effective, must not be cartel-like. Rather, it should be simple and nonbinding and function as a "benchmark" that would help to harmonize the activities of the many judges who desired coordination. The discussion led to the formation of an Ad Hoc Committee on Timing of Law Clerk Interviews.

With the encouragement of the Ad Hoc Committee, Guido Calabresi, then Dean of the Yale Law School, wrote to every law school dean in the nation. ${ }^{17}$ Dean Calabresi's letter brought a tidal wave of endorsements for the Ad Hoc Committee's March 1 benchmark proposal. ${ }^{18}$

Question \#2 (Suggested Date)

$\begin{array}{lr}\text { December 1 } & 1 \\ \text { January 1 } & 3 \\ \text { February 1 } & 22 \\ \text { March 1 } & 39 \\ \text { April 1 } & 40 \\ \text { May 1 } & 1 \\ \text { June 1 } & 3 \\ \text { June 15 } & 1 \\ \text { July 1 } & 2 \\ \text { September 1 } & 2 \\ \text { October 1 } & 2 \\ \text { NO DATE } & 29\end{array}$

Question $\# 3$ (Or should we simply forget the whole business?)

$\begin{array}{ll}\text { Yes } & 29 \\ \text { No } & 98 \\ \text { Blank } & 18\end{array}$

Memorandum from Judge Becker to All Circuit Judges 1-2 (Feb. 2, 1993) (tabulating results of questionnaire).

17. See, e.g., Letter from Dean Calabresi to Mark A. Nordenberg. Dean. University of Putsburgh School of Law 1 (June 22, 1993) (encouraging Dean Nordenberg to write to Judicial Conference indicatıng whether or not he supported the guidelines) (on file with Judge Becker).

18. Deans from the following 66 law schools, constituting approximately $40 \%$ of the accredited law schools in the nation, answered Dean Calabresi's letter by endorsing the Ad Hoc Committee's March 1 benchmark proposal in the strongest terms: The American University, Anzona State University. Benjamin N. Cardozo School of Law, Boston College, Boston Unversity. Bndgepon School of Luw. Brooklyn Law School, Capital University, Chicago-Kent College of Law. College of Willuam and Mary. Columbsa University, DePaul University. Duke University. Emory University. Fordham University. George Mason University, Georgetown University, Golden Gate University. Harvard University. Howard University. Indiana University, John Marshall Law School, Louisiana State Universily, Memphis State Unıversily, New York Law School, Northwestern School of Law of Lewis \& Clani College. Notre Dame Law School. Pace University, Peppendine University, Rutgers University (Newark). St. John's University. St. Mary's University, Santa Clara University, Southem Illinois University (Carbondale). Stanford Law School. Temple University, Thomas M. Cooley Law School. Touro College. Tulane Law School. University of Arkansas. University of Chicago, University of Cincinnati. University of Colorado. University of Detroit Mercy. University of Idaho, University of Kansas, University of Kentucky. University of Louisville. Untversity of Maine, University of Michigan, University of Minnesota, Unıversity of Mississippı. Universıty of Missoun. Columbia, University of North Carolina (Chapel Hill). University of Oklahoma. Unuverstly of Pennsylvania. University of San Diego, University of Southern Califomia, Universily of Tennessee (Knoxville). Universily of Toledo, University of Virginia, University of Wyoming. Washbum Universıly. Washıngton Unıversıty (St. Louis), Wayne State University, and Widener University. Letlers on file with Judge Becker 
A few excerpts from these letters are telling:

The recent acceleration of the clerkship selection process has been very disruptive to the educational process here at the Duke Law School, as students have scrambled to apply for clerkships early in their second year, when they have barely begun taking advanced courses and working on journals. It is difficult for faculty to write effective recommendations for students so early in the process as these students have not yet had the opportunity to demonstrate their intellectual abilities in smaller elective courses and seminars. The chaotic timetable also has caused a great deal of uncertainty for those of us who advise students about how and when to apply for clerkships. ${ }^{19}$

And:

The existing state of affairs is nothing short of absurd. It demeans the federal judiciary, undermines the educational process and results in judges making their selections on the basis of inadequate information. $^{20}$

Armed with the law deans' letters, the Ad Hoc Committee persuaded the Judicial Conference to pass the March 1 resolution unanimously at its September 1993 meeting. ${ }^{21}$ All judges and law deans were then notified of its terms. As the interviewing season approached, Dean Calabresi suggested to the deans of other law schools that they ask their students not to apply and their faculty not to send letters of recommendation until at least three weeks before the March 1 date. ${ }^{22}$ The deans agreed. ${ }^{23}$ Robert C. Clark, Dean of the Harvard Law School, then wrote a letter on behalf of fourteen other deans to all federal judges stating that "we have now asked our students not to send

19. Letter from Susan L. Sockwell, Associate Dean, Duke University School of Law, to Judge Becker 1 (June 30, 1993) (on file with Judge Becker).

20. Letter from Geoffrey R. Stone, Dean, University of Chicago Law School, to Judge Becker I (July 7,1993 ) (on file with Judge Becker).

21. See supra notes $1-2$ and accompanying text.

22. See, e.g., Letters from Dean Calabresi to the Deans of the law schools of Columbia University, Georgetown University, Harvard University, New York University, Northwestern University, Stanford University, University of California at Berkeley, University of California at Los Angeles, University of Chicago, University of Michigan, University of Pennsylvania, University of Southern California, and University of Virginia (Oct. 8, 1993) (suggesting that deans can urge "students not to apply prematurcly" and that faculty can "refuse to send recommendations by letter or by phone until three weeks prior to the March (st date") (on file with Judge Becker); $c f$. Memorandum from Robert C. Clark, Dean, Harvard Law School, to Faculty, Staff and Students [of Harvard Law School] I (Oct. 15, 1993) (announcing that "[s]tudents applying for federal clerkships beginning [in the] Fall 1995 should not submit application materials" and "[f]aculty members should not send letters of recommendation in support of 1995 federal clerkship applications before February 1, 1994") (on file with Judge Becker).

23. E.g., Letter from Robert C. Clark, Dean, Harvard Law School, to Dean Calabresi I (Oct. 20, 1993) (exclaiming "Bravo! Your letter of October 8 regarding the Judicial Conference was most appropriate") (on file with Judge Becker). 
applications to judges before February 1, and our faculty not to send out recommendations before the same date." 24 The posting of Dean Clark's letter settled the final design of the March 1 Solution.

\section{The March 1 INTERVIEW DATE-RESUltS AND ReACTIONS}

The vast majority of judges complied with the March 1 Solution. With the apparent exception of the Eighth Circuit, the defections that were reponed were minor in both number and effect. Some Ninth Circuit judges let it be known that they would conduct interviews over winter break with students who were attending law schools away from the West Coast and who were returning for vacation, though they would not extend offers until at least March 1. A number of judges in other circuits announced similar intentions. The designs of those judges who desired to repeat the previous years' practice of interviewing and hiring in December and January, however, were largely frustrated by a lack of applicants prior to February $1 .^{25}$ After February 1, judges received applications, but most continued to wait until March 1 to interview.

We acknowledge that, although the vast majority of judges abided by the March 1 date, others did not. One law dean, while heralding the general success of the March 1 deadline, opined that it "appears to have been violated much more often than the February 1 starting date for applications and letters of recommendation. 'Open season' did seem to begin during the month of February, although it lacked the frenzy of activity we have sometimes witnessed in the past." 26 This phenomenon appears to be, in large measure, a result of the willingness of students and professors to abide by the March 1 date. Indeed, the authors have received anonymous reports that students from some law schools, acting on the advice of their clerkship advisers, declined

24. Letter from Robert C. Clark, Dean, Harvard Law School, to Alt Federal Coun Judges 1 (Oet 25. 1993) (signed by Dean Clark on behalf of Dean Judith C. Areen. Georgetown University Law Center. Dean Robert W. Bennett, Northwestern University School of Law; Dean Scolt H. Bice, Unversity of Southem California Law Center; Dean Lee C. Bollinger, University of Michigan Law School: Dean Paul A Brest. Stanford University School of Law: Dean Guido Calabresı. Yale Law School: Dean Colin S Diver. University of Pennsylvania School of Law; Dean Herma Hill Kay. University of Califorma at Berkeley School of Law (Boalt Hall); Dean Lance M. Liebman, Columbia University School of Law. Dean Susan Westerberg Prager, University of California at Los Angeles School of Lar: Dean Robert E. Scott. University of Virginia School of Law: Dean John E. Sexton. New York University School of Law: Dean Geoffrey R. Stone, University of Chicago Law School; and Dean Mark G. Yudof. University of Texas School of Law) (on file with Judge Becker).

25. Some law schools whose students tend to apply for clerkships in those circuits with judges who announced that they would interview prior to March I felt they had "no choice but to contunue to comply with individual deadlines." Letter from Richard S. Winz. Dean. University of Tennessec al Knoxville College of Law, to Dean Calabresi I (June 7. 1994) (emphasis added) (on file with Judge Becker). Our impression, however, is that most law students and faculty commendably hewed to the February 1 date for applications and letters of reference.

26. Letter from Rober E. Scoth, Dean. University of Virgınia School of Law, to Dean Calabresi 1 (June 16, 1994) (on file with Judge Becker). 
invitations to pre-March 1 interviews. Similarly, some students who did agree to early interviews complied with the spirit of the guidelines and declined to accept clerkship offers prior to March 1.

Moreover, the overwhelming majority of judges interviewing before March 1 , including those on the Ninth Circuit, apparently refrained from making job offers until on or after March 1. Judges who made offers precisely on March 1 reaped a certain competitive advantage over those who did not commence interviewing until March 1, but the advantage seems to have been inconsequential. Indeed, our reports from deans of law schools in the Ninth Circuit reflect general satisfaction with the March 1 program. ${ }^{27}$ Eighth Circuit judges were the least willing to follow the March 1 benchmark date for extending offers, and many Eighth Circuit judges also conducted interviews prior to February 1 during the holidays with students who had returned home for vacation.

Although we cannot speak with scientific accuracy, we can draw several reliable conclusions on the basis of reports from members of the Ad Hoc Committee, other judges throughout the nation, and law deans: (a) that the vast majority of law students and professors honored the February 1 application/letter of recommendation date; and (b) that most federal judges honored the March 1 benchmark date for the commencement of interviews.

\section{ADVANTAGES OF THE MARCH 1 SOLUTION}

Based upon a survey of law deans, the law schools in general seem quite pleased with the results of the March 1 Solution. ${ }^{28}$ Prior to implementation of the benchmark date, the law school deans articulated several problems with the existing "free market" in clerkships-all of which were substantially alleviated by the March 1 reform.

27. See, e.g., Letter from Scott H. Bice, Dean, University of Southern California Law Center, to Dean Calabresi I (June 20, 1994) ("IT]he time table went a long way towards restoring sanity to the nearly outof-control process.") (on file with Judge Becker); Letter from Paul Brest, Dean, Stanford University School of Law, to Dean Calabresi 1 (June 28, 1994) (stating that "[p]ostponing the clerkship process noticeably reduced the student anxiety," but that "students at West Coast Schools considering clerkships in the Enst may be particularly disadvantaged because ... most of the judges refusing to follow the guidelines are in California") (on file with Judge Becker); Letter from Herma Hill Kay, Dean, University of California at Berkeley School of Law (Boalt Hall), to Dean Calabresi 1 (July 21, 1994) (stating that "postponing the start of the application and interviewing achieved its most important goals" and urging that applications and interviews be "postponed until the summer after second year" to "reduce the relative disadvantages of West Coast students") (on file with Judge Becker).

28. See Letters from the deans of the law schools of Boston College, Creighton University. Duke University, Emory University, Harvard University, Indiana University, Louisiana State University, Mercer University, Mississippi College, New York University, Northwestern University, Ohio State University, Rutgers University (Newark), Seton Hall University, South Texas College, Temple University, University of California at Berkeley, University of Cincinnati, University of Detroit Mercy, University of Florida, University of lowa, University of Maryland, University of Mississippi, University of Missouri, University of Southem California, University of Toledo, Wayne State University, and Widener University, to Dcan Calabresi (received in June and July 1994) (on file with Judge Becker). 
As noted above, the deans had argued that the early clerkship season had three particularly harmful effects. First, it interfered with classes because students often had to take several trips to obtain a clerkship. Second, it denied students the opportunity to adjust to the rigors of law school and to obtain a desirable clerkship based on their performance after their first year. Third, it prevented students from focusing their interests in law before deciding whether to apply for a clerkship. The early clerkship season also forced judges to make decisions based only on first-year grades and recommendations from faculty members who only had contact with students in large first-year classes.

The March 1 arrangement alleviated most of the deans' concerns. By the time of hiring, most judges had students' third-semester grades in addition to first-year grades. Faculty members provided more informative recommendations for students who had taken small upper-level seminars. And students had more time to think about whether and where they really wanted to clerk.

There were other advantages of the March 1 reform. The most frequent comment from the law deans was that the March 1 Solution provided students much more certainty as to when to apply and enabled them to concentrate more on their fall semester studies and exam preparations. With additional time available at the beginning of the spring semester, students could more effectively prepare application materials and arrange for faculty references. And the February 1 application date afforded students more time to research and apply to a wider range of judges.

The responding deans also commented that the March 1 arrangement had done much to eliminate the informal but gripping rumor mill about when students from different law schools had sent out applications and what judges or circuits were about to hire. The unreliability of such information had, in the past, increased student anxieties in what is at best a stressful process. As one dean put it, the students liked the fact that there was "less of a premium on being connected to a good "grapevine." ${ }^{29}$ We do not mean to suggest that the March 1 Solution eliminated student anxiety over early hiring. That would be too much to expect, especially because no one was sure how the first year of the March 1 program would work. We believe, however, that the March 1 benchmark substantially reduced stress and that, in the wake of the generally successful results, the second and subsequent years of the program will see still further reduction in tensions if law schools hold the line.

The March 1 Solution was also kind to students on the important issue of interviewing expenses. Since most judges were conducting interviews at about the same time, students were able to schedule multiple interviews for the cost

29. Letter from Robert C. Clark, Dean, Harvard Law School, to Dean Calabrest I (July 20, 1994) (on file with Judge Becker). 
of one round-trip airfare. ${ }^{30}$ The grouping of interviews helped student couples coordinate their clerkship searches. Students also seemed to like the longer break between the search for summer placement and the clerkship search.

In general, the consensus was that the process was much less frantic and disruptive than in previous years, not only for the students, but also for law school faculties and administrators. ${ }^{31}$ Administrators, who had previously found it difficult to organize efficient administrative support for clerkship recommendation letters and applications because the "season" could start without warning, were now able to schedule secretarial and administrative support productively and arrange for timely informational meetings and counseling.

For example, the clerkship advisor for the University of Michigan Law School, where the secretarial staff sent approximately 10,000 reference letters to judges last season, reported that the process ran smoothly this year because the timing of the letters was known well in advance and because most students had the leisure to approach professors for their letters of recommendation at least a month before they were due. Faculty liked having the recommendation process concentrated in a few weeks. ${ }^{32}$

One law dean summed up all these concrete and salutary consequences as follows:

We believe the timetable went a long way toward restoring sanity to a nearly out-of-control process. Very few of our students complained that they were disadvantaged by complying with the timetable; the vast majority of our applicants and their faculty recommenders expressed profound gratitude for the spring hiring schedule. $^{33}$

The reaction from the judges has also been generally positive, although somewhat more mixed than that from the law schools. Most judges are pleased

30. On a practical level, the free-market approach to the hiring process is extremely expensive for students. When judges operate on different timetables, applicants may have to fly long distances for each interview. Airfares are prohibitively expensive to some applicants. This is especially true since the frecmarket interview schedule will normally not accommodate an economy fare. The fact that the high cost of air travel prices many students out of the national clerkship market alone compelled the writers to urge the Judicial Conference to support the March 1 Solution as "the right thing to do." Memorandum from Judge Becker and Chief Judge Breyer to Members of the Judicial Conference 7 (Sept. 8, 1993) (on file with Judge Becker).

31. See, e.g., Letter from Scott H. Bice, Dean, University of Southern California Law Center, to Dean Calabresi 1 (June 20, 1994); Letter from Robert E. Scott, Dean, University of Virginia School of Law, to Judge Becker I (June 16, 1994) (noting absence of "frenzy of activity" typical of past years); Letter from Susan L. Sockwell, Associate Dean, Duke University School of Law, to Dean Calabresi I (Junc 13, 1994) (claiming the March I Solution is "extremely helpful to those of us who work with both students and faculty during the clerkship application process") (on file with Judge Becker).

32. Letter from Deborah C. Malamud, Assistant Professor of Law, University of Michigan Law School, to Judge Becker 2 (May 13, 1994) (on file with Judge Becker).

33. Letter from Scott H. Bice, Dean, University of Southern California Law Center, to Dean Calabresi 1 (June 20, 1994) (on file with Judge Becker). 
with the program and urge its continuation. They seem to find particularly attractive the fact that the program allows them to confine the interviewing process to a discrete block of time, even though it makes for a very busy period. Under the March 1 reform, judges were able to complete the interviews and selections within a few weeks, permitting comparisons between applicants still fresh in their minds, and they were able to meet a fair sampling of the best applicants. ${ }^{34}$

Nevertheless, the March 1 deadline, far from a panacea, engendered a few problems of its own. Given the history of this process, law school clerkship advisers remained cautious and apprehensive, largely because they were not sure which judges would observe the March 1 benchmark. A number of deans mentioned the "rumor problem" that scared some students into applying before February $1 .^{35}$ And a number of facuity members faced the problem of whether to supply a letter of recommendation in December or January to a judge who was not abiding by the arrangement. ${ }^{36}$ It seems that some faculty members did, believing it was in the best interests of their particular students, while others did not, believing it was in the best interest of students overall. Some students faced the dilemma of whether to accept offers that were tendered before March 1 . Apparently most students accepted the early offers, though, as noted above, we know of students who consulted with their school's clerkship committee and respectfully declined. ${ }^{37}$

Although the plan had the desired effect of bringing more predictability and composure to the process, it meant that both interviews and offers bunched around the March 1 date, so students had little latitude in scheduling interviews. Unfortunately, although the offers now tended to be bunched together, students still felt compelled to accept the first offer rather than wait for news from a judge with whom they might have been the best match.

34. As Judge Sifton acutely observed:

Whether intended or not, the March I staring date for interviews effoctucly imposed a matching system which, as you note, provided some minımal ratıonalıty Judges gave preference in scheduling to applicants who looked best on the basis of their wniten submisstons coffenng an interview date on or close to March 1). Applicants accepted early interview dates with those judges they knew they wanted to work for. As a result the interview season for me and a number of other judges started and ended on March 1.

Letter from Charles Sifton. District Judge. U.S. District Coun for the Eastern Distnct of New York, to Jon O. Newman, Chief Judge. U.S. Court of Appeals for the Second Circuit 1 (June 9. 1924) (on file with Judge Becker).

35. See, e.g., Letter from Professor Barbara Bennett Woodhousc. Professor Frank Goodman, and Jo Ann Verrier, University of Pennsylvania School of Law, to Judge Becker 2 (May 23. 1994) ("Rumors about judges interviewing early were still a problem, although on a far smaller scale.") (on file with Judge Becker).

36. See, e.g., Letter from Paul Brest, Dean. Stanford Unversity School of Law, to Dean Calabresi 1 (June 28,1994 ) (claiming that numerous judges "sought and obtanned evaluations of candidates by phone from faculty members of various [other] instututions." but that "Stanford faculty adhered in the guidelines--to our students' comparative disadvantage") (on file with Judge Becker).

37. Interview with anonymous student, Yale Law School, J.D. '94. by Judge Becher (Mar 3. 1994) (regarding offer by First Circuit judge). 
It should come as no surprise that some judges have voiced displeasure with the March 1 arrangement. Much of the dissatisfaction is arrayed along geographical lines because of the perceived advantage held by judges on the East Coast. For example, a Texas judge complained that the de facto shortening of the interview period compounded the advantages of the East Coast judges, because so many top law schools and judges are concentrated on the East Coast. Apparently, judges in the Northeast corridor benefit from students' desire to schedule their initial interviews along the eastern seaboard where quick and inexpensive travel between chambers enables them to schedule multiple prime interviews in a short time frame. ${ }^{38}$

Also as a result of the perceived advantage for judges on the East Coast, some Ninth Circuit judges interviewed before March 1. For the coming season, while they still seem intent upon interviewing before the benchmark date, they seem to be willing to withhold offers until March 1. As one judge wrote:

Our deviation from the March 1 date [for interviewing] did not work any particular unfairness on clerkship applicants because, as far as I know, we did not insist on immediate answers from students who told us that they were interested in talking to a couple of East Coast judges first. Most, if not all of us, told such applicants that they could delay responding to our offers and take a day or two for East Coast interviews. $^{39}$

As can be expected from such a large and diverse group of individuals, a few judges do not intend to support the March 1 benchmark. One judge from a mountain state lamented that because of the high cost of air fare and the difficulty of combining an interview with interviews in other cities within a short time frame, only students who have targeted a particular city in his area as their first choice were likely to come there on March 1. And apparently relatively few students who attend school on either coast target geographically remote cities such as his. He therefore intends to interview earlier from now on, though he expressed support for an "offer date," because it creates a longer time period for interviews. ${ }^{40}$ In contrast, an Eighth Circuit judge, apparently

38. Memorandum from Jerry E. Smith, Circuit Judge, U.S. Court of Appeals for the Fifth Circuit, to Emilio Garza, Circuit Judge, U.S. Court of Appeals for the Fifth Circuit 1-2 (May 20, 1994) (on file with Judge Becker).

39. Letter from Stephen Reinhardt, Circuit Judge, U.S. Court of Appeals for the Ninth Circuit, to Judge Becker 1-2 (May 31, 1994) (also noting that "we would be better off selecting clerks after the start of their third year in law school" and "there should be a period for interviews before the opening date for job offers" so that applicants could "see all the judges in whom they are interested and judges could sce however many applicants they wish[ed]") (on file with Judge Becker).

40. Letter from Monroe G. McKay, Circuit Judge, U.S. Court of Appeals for the Tenth Circuit, to Judge Becker I (May 13, 1994) (on file with Judge Becker). 
expressing opposition to the perceived regimentation, proclaimed: "I am bailing out of the cartel. Let a thousand flowers bloom."

\section{Other PRoposals}

Judges Wald, Kozinski, and Oberdorfer have each in turn proposed solutions to the law clerk selection problem. ${ }^{42}$ There is much to commend in each of their proposals. But the pages of history we have recounted demonstrate that each of the approaches previously advanced possesses a serious flaw.

The most ambitious and theoretically sound proposal is the medical school matching model first recommended by Judge $\mathrm{Wald}^{33}$ and later endorsed by Judge Oberdorfer. ${ }^{44}$ The medical match system would work essentially as follows: On a specified date, presumably sometime in the fall of the third year, each student and judge would rank his or her preferences on a form and file it with a central clearinghouse. A few days later, each student and judge would receive a computer printout of his or her preferences to check for errors. Once these were verified, a program would automatically match each judge with students whom that judge ranked highest and who ranked that judge highest. Once the rankings were completed, students and judges would be notified of their matches and would be required to accept them unless a good reason could be certified. Any judges with leftover positions would be free to offer them to any unmatched students. ${ }^{45}$

Judge Kozinski has written an extensive critique of the medical match system. ${ }^{46}$ One need not endorse all his criticisms to conclude that the match system would not solve the judicial clerkship problem. Judge Kozinski's point that the match procedure would not permit judges to create a "mix," or build a team of clerks whose skills and backgrounds complement and balance each other, is well taken. As Judge Kozinski noted:

Many judges consider geographical, racial and gender balance to be important, but not necessarily crucial, provided other criteria are met. Other judges may want at least one clerk who has served on a law

41. Letter from Morris S. Arnold, Circuit Judge. U.S. Court of Appeals for the Eighth Circult, to Judge Becker I (May 13, 1994) (on file with Judge Becker).

42. In 1990, Chief Judge Patricia M. Wald first proposed the "medical match" system for clerkshup applicants. Patricia M. Wald, Selecting Law Clerks, 89 MICH. L. REv. 152 (1990). In 1991. Judge Alcx Kozinski severely criticized the medical match model and strongly advocated the free-markel approsch. Alex Kozinski, Confessions of a Bad Apple, 100 YALE L.J. 1707 (1991). More recently. in 1992, Judge Louis F. Oberdorfer re-proposed the medical match system. Louss F. Oberdorfer \& Michzel N. Levy. On Clerkship Selection: A Reply To The Bad Apple. 101 YALE L.J. 1097 (1992).

43. Wald, supra note 42.

44. See Oberdorfer \& Levy, supra note 42.

45. This type of system has been used for many years to match graduaung medical students with residencies at hospitals and other medical institutions.

46. See Kozinski, supra note 42 , at 1720. 
review, or who has taken certain courses, or who comes from a particular school. Age and non-law experience may be an important factor in the mix; if you have two young, male hot dogs you may deem it particularly important to have a third clerk who is a bit older, or female, or who has had a prior career. Equally important are the intangible factors: How will a particular set of clerks get along with each other and the rest of the judge's staff? ${ }^{47}$

While there is much to be said for Kozinski's view, there is another simpler reason to reject the medical match model, and an irresistible one: Judges find it unacceptable. In the 1989 survey, only one-third of the judges voted in favor of the match system. And the failure of five less ambitious attempts at reform suggests the futility of such a radical alternative. Indeed, most consistent with the theme of this Essay is the reaction of Judge Richard Cudahy of the Seventh Circuit, who observed that a "simple date like this was all that could be fruitfully suggested," and that "anything more sophisticated [would be] likely to break down." ${ }^{38}$

Although we agree with Judge Kozinski's criticisms of the medical match system, we do not believe that his "free-market" solution is acceptable. The free-market approach has, after all, led to both the problems that have brought the process into disrepute and the continuing efforts at reform. Judge Kozinski argues that no alternative to the free-market system will eliminate its faults. Our one-year experience with the March 1 benchmark, however, strongly suggests the contrary. We entertain no illusions that the March 1 Solution is perfect, but we respectfully submit that, like democracy with all its flaws, it is the best system that anyone has conceived thus far. ${ }^{49}$

\section{SOME SUGGESTED MODIFICATIONS}

Although we believe that the modest March 1 Solution is the best system presently attainable, we view it as not having defeated one major shortcoming of the hiring process: the fact that many judges still require applicants to accept offers either on the spot or within an unreasonably short time-as little as forty-eight or even twenty-four hours. Such "exploding" or "short-leash" offers result in unfairness to applicants who, quite reasonably, would like the opportunity to interview with other judges in the hopes of securing the most

47. Id. at 1722 .

48. Letter from Richard Cudahy, Circuit Judge, U.S. Court of Appeals for the Seventh Circuit, to Judge Becker 1 (May 16, 1994) (on file with Judge Becker).

49. See Winston Churchill, Speech to the House of Commons (Nov. 11, 1947), in 7 WINSTON S. ChuRChill: His COMPLETE SPEECHES, 1897 to 1963, at 7566 (Robert R. James ed., 1974) ("[1]t has bec" said that democracy is the worst form of Government, except all those other forms that have been tricd from time to time."). 
desirable offer in terms of judge and location. The problem is especially acute for "student couples" who wish to clerk in the same vicinity.

The decision to accept or reject an exploding offer can be exceedingly anguishing when an interview is beckoning elsewhere. The imposition of shortleash offers is also unsporting toward other judges, particularly those geographically dispersed, who would also like to interview and perhaps make an offer to the applicant. Unfortunately (and undeniably), the urge of some judges to snare a desirable candidate and to prevent comparison shopping is strong.

Furthermore, the untoward effect of this exploding-offer syndrome has been exacerbated by the "conventional wisdom" propagated in many law schools that applicants are obliged to accept the first offer tendered. We find this state of affairs inexplicable and indefensible; because it is so terribly inequitable to the students, we do not understand how or why it ever gained acceptance. The explanatory note to the Judicial Conference resolution addressed and debunked the theory that students are obliged to accept the first offer tendered, but unfortunately that portion of the explanatory note to the resolution has not been publicized. The authors urge law school deans and faculty to act immediately to counter the conventional wisdom and to counsel students instanter that they are not obligated to accept, and should request a reasonable time to consider, an offer for a judicial clerkship.

With respect to the continued tendency of some judges to require answers in a short amount of time or even immediately, the authors believe that fundamental fairness and optimal placement require that a student be given a minimum of three working days to a week to accept an offer, with the option of an extension for good cause shown. This timetable should allow the student to pursue other options; but it is not so protracted as to prejudice the judges who would like to assemble a clerkship team and return to judicial business. Dean Paul Brest of Stanford University School of Law has strongly advanced a five-day minimum rule ${ }^{50}$ that seems to be winning broad support in the academy.

The authors also believe that the best possible time to select applicants would be the fall term of their third year in law school." The law deans generally favor this approach. ${ }^{52}$ This "fffth semester" approach would give the

50. Letter from Paul Brest. Dean. Stanford University School of Law, to Dean Calabresi 1 ujune 28, 1994) (on file with Judge Becker).

51. A date during the second year that is later than March I. whle seemingly destrable, presents practical problems because the March I date permits intervieu'ing dunng spnng breah. While a later date loses this advantage and may conflict with examinations. March I docs, unfortunately. create problems for schools on a "quarter system." See Letter from Elena Kagan. Professor. University of Chicago La" School. to Dean Calabresi I (June 4, 1994) (noting the "senous problem" of Interileus laking place dunng cxam week and urging either an April 1 date or interviews in the summer after the second year with offers in the fall) (on file with Judge Becker).

52. See, e.g., Letter from David P. Currie. Interim Dean. University of Chicago Luw School. to Judge Becker 1 (June 1, 1994) (on file with Judge Becker). 
applicant more time to compile a well-rounded record and minimize the disruption of study periods and exams. Such a regime would also furnish judges with the benefit of a full two years of law school accomplishments as well as summer employment to consult when making clerkship decisions.

Moreover, if the fall deadline were made into an offer date (i.e., a program whereby the only constraint was the date before which an offer could not be made), interviews could be permitted throughout the summer to maximize flexibility. Sentiment in favor of summer interviewing runs extremely strong on the West Coast, where the judges see the summer after the second year as the optimum period for interviews. ${ }^{53}$ Unfortunately, we discern a problem vexing the summer interview program. Having an offer date rather than an interview date seems to be the reason that the approach tried during the 1990 clerkship interview season-where interviews could be held at any time but offers had to be reserved until May 1 at noon EDT-came crashing down. Indeed, it crashed so hard that the judges essentially wanted no more part of it, and most judges with whom we have spoken continue to want no part of it. Pushing the interview date back to the fall of the third year is somewhat more realistic, and likely to be advantageous, but does not seem to have enough support to be implemented any time soon.

\section{CONCLUSION}

The Judicial Conference resolution has no "sunset" provision and hence as a statement of policy it is ongoing. Rejection of the nonbinding program by a large number of federal judges would destroy it, but as the foregoing discussion suggests, there is no reason to believe that such widespread defections will occur. We can expect that judges from areas of the country with fewer law schools, and perhaps some judges in the Midwest and on the West Coast, will conduct interviews before March 1, but it appears that only a handful of those who do will extend offers before then. The pool of highly qualified applicants is sufficiently numerous that a small number of defections will not undermine the proposal.

That is not to say that we encourage defections; we would prefer all federal judges to abide by the March 1 solution. But we recognize that judicial perception of special problems in certain geographic regions will lead a modest number of judges to interview before March 1 . We nonetheless envision that these judges, motivated by respect for the Judicial Conference resolution, will not make offers until and preferably after March 1 . We also believe that the vast majority of federal judges will continue to honor the March 1 interview

53. See, e.g., Letter from Herma Hill Kay, Dean. University of California at Berkeley School of Law (Boalt Hall), to Dean Calabresi I (July 21, 1994) (on file with Judge Becker). 
date. It is noteworthy that many federal judges have never interviewed before that date anyway.

After all is said and done, law students and faculty hold the trump card. If the students and faculty adhere to the February 1 and March 1 benchmark dates, the judges will simply be unable to impose their own designs on the process. As evidenced by the letters expressing overwhelming support for the March 1 Solution, ${ }^{54}$ it seems likely that a majority of law school deans will continue their efforts. Indeed, recent communications among the law deans suggest that they are already at work on obtaining a consensus for the 1995 clerkship season that will not only replicate what was accomplished in 1994. but strengthen it by asking faculty to refrain from making oral recommendations as well as written ones before February 1.

We have remarked on our conviction that pushing back the benchmark date for commencement of interviews until September of the third year of law school would improve upon the system even more. We hope that a few years of satisfactory experience with the March 1 Solution will lead to a broad consensus for a later date. For now, the habit of hiring during the second year seems to have become strongly ingrained, and old habits die hard. Thus, under the circumstances, our recommendation to students, law schools, and judges for the 1995 hiring season and beyond is to adhere to the Judicial Conference resolution (and its explanatory note)-that is, (a) applications and faculty recommendations should not be submitted until on or after February 1; and (b) interviews should not be conducted, and offers should not be extended, until on or after March 1. We also encourage law schools to inform students that they are not obliged to accept the first offer tendered, and we encourage judges to hold offers open for a reasonable time-from three working days to a week - with the option of an extension for good cause. We truly believe that this March 1 Solution will not only "hold," but also mature and improve. Toward that end, we urge our colleagues at the district court and appellate levels in the federal judiciary, our friends in the academy, and the clerkship applicants to help make it work.

54. See supra note 28. 
